\title{
Women's Empowerment and Fertility Behaviour among the Tribals of Rajasthan, India
}

\author{
Hemant Patidar ${ }^{\dagger}$
}

\section{Abstract}

Fertility has declined in India during the last few decades because of socio-economic development. Women's empowerment has been identified as an important determinant for demographic change. Tribals in India have relatively high fertility because of their traditional sociocultural practices and poor economic condition. This study aims to examine the role of women's empowerment on fertility behaviour by utilising primary data collected from ten tribal dominated districts of Rajasthan. These tribal communities belong to the Bhils, the Meenas and the Saharias. Results reveal that women's empowerment is negatively associated with fertility behaviour. Women's education, employability, participation in decision-making, exposure to media and spousal communication bear significant impact on fertility behaviour. This study may have some implications for future studies and policy makers for regulating fertility.

Keywords: women's empowerment, fertility behaviour, ever-married woman, children ever born, tribals, Rajasthan, India

\footnotetext{
${ }^{\dagger}$ Assistant Professor, Department of General and Applied Geography, Doctor Harisingh Gour Vishwavidyalaya, Sagar, Madhya Pradesh, India-470003, Email: hpatidargeog@gmail.com

C2018 Patidar. This is an Open Access article distributed under the terms of the Creative Commons Attribution License (http://creativecommons.org/licenses/by/2.0), which permits unrestricted use, distribution, and reproduction in any medium, provided the original work is properly cited.
} 


\section{Introduction}

The world population has increased alarmingly notably in the latter half of the 20th century, which has caused hindrances to human development. This increase in population is mainly from the developing countries of South Asia and Sub Saharan Africa (United Nations, 2015). Fertility is observed to have declined in many South Asian countries despite the continued low level of economic development. This is perhaps due to the empowered status of women in households and society (Phan, 2016). The importance of women's empowerment in demographic transition has long been recognised by many international agencies. The United Nations (1996) has been emphasising the role of women in demographic processes since the Fourth World Conference on Women held in Beijing in 1995. The United Nations identified five components of women's empowerment. First, women's sense of selfworth; second, their right to have and to determine choices; third, their right to have access to resources and opportunities; fourth, their right to have the power to control their own lives both within and outside the home; fifth, their ability to influence the direction of social change to create a more just social and economic order nationally and internationally (United Nations Population Information Network, 1995).

In 1999, Kabeer defined women's empowerment as the 'ability to make choices', access to the resources that improve the freedom to make choices and ability to define one's goals and act on them. Various forms of empowerment operate in relation to different forms of power (Rowlands, 1995, 1997; see also Bhattacharyya, 2009, Bhattacharyya and Vauquline, 2013). Rowlands (1995; 1997) identified four forms of power that remains critical to women's empowerment. They arepower over- power that enables to dominate others; power with - power formed by collective acts/actions; power within - this is the power that helps an individual to develop self-confidence and power to -this form of power enables to transform or build change.
Bhattacharyya (2009); Bhattacharyya (2016) and Bhattacharyya and Vauquline (2013) applied Rowland's concept of empowerment to scrutinise Indian women's changing status and roles at different hierarchies.

Women's empowerment has been one of the development goals for the millennium since 2000. However, post 2015; it has been proposed as the Sustainable Development Goals (SDGs) of the United Nations (United Nations, 2015). Moreover, the United Nations has strongly emphasised on the role of women's education and employment in fertility decline in its most recent report, Gender Equality and Sustainable Development (United Nations, 2014). Scholars argue that the empowered status of women in the society leads to gender equality that reduces female infanticides and balances demographic structure (Jacobson, 1992). Hence, women's empowerment has been observed as a significant contributing factor to more balanced sex ratios at births in some Asian societies (Gupta, 1996). Several studies prove that the employment status of paid workers is also associated with lower fertility (Jejeebhoy, 1995; Rindfuss and Brewster, 1996; Kabeer 2005). The increasing autonomy and empowerment among women not only influence their family structure but its next generations.

According to the National Family Health Survey, India-Report-2015-16, (NFHS-4) has experienced 22.73 per cent decline in total fertility rate (TFR) from 2.7 in 2005-06 to 2.2 in 2015-16 (IIPS, 2017). However, there are differences in fertility due to diverse spatial, socio-cultural, economic and institutional factors. The scheduled tribes (STs), which is 8.4 percent of the total population of India (Census, 2011), has very high TFR (2.48) when compared to the Scheduled Castes (SCs) (2.26), Other Backward Class (OBCs) (2.22) and others (1.98) (IIPS, 2017). ${ }^{1}$ The high fertility among the

\footnotetext{
1 The historically marginalised groups of India are recognised as Scheduled Castes (SCs) and Scheduled Tribes (STs) by the Constitution of India, while the Other Backward Class (OBCs) is the community, which is socio-
} 
STs is because of their long traditional socioeconomic values and cultural taboos (Nagda, 2003).

Rajasthan, one of the Empowered Action Group (EAG) states $^{2}$ is far behind the others states in many human development indicators. The female literacy rate (52.66 per cent) in Rajasthan is the lowest among all Indian states and Union Territories (UTs). The STs of the state constitute 12.6 per cent of the total population. The female literacy rate among the STs (30.52 per cent) is meagre (Census, 2011). However, the fertility rates among the STs in Rajasthan are also very high (TFR 2.86) compared to the SCS (TFR 2.61), OBCs (TFR 2.37) and the Others (TFR 1.94). It is believed that the status of women of the other communities has increased concerning education and employment, and this has influenced their fertility behaviour.

Many studies have shown strong associations between tribal women's enhanced socioeconomic status and their fertility outcomes (Patidar, 2015; Singh \& Patidar, 2012; Bhardwaj \& Tungdim, 2010; Nanda, 2005; Roth et al., 1983; Verma, 1977; Nag, 1973, United Nations, 1961; Majumdar, 1947). These studies have examined the role of women's empowerment on fertility, and demographic transition but very little is known about tribal women's fertility behaviour. This study, therefore, is an effort to examine the impacts of women's empowerment on fertility behaviour.

The study begins with the discussion of the materials and methods deployed. Following this, the results and discussions are outlined.

\section{Materials and Methods}

The research is based on primary data, collected from ten tribal dominated southeastern districts of Rajasthan. It draws on

\footnotetext{
economically plus educationally marginalised (Bhattacharyya, 2009; 2013).

${ }^{2}$ In India, the eight socioeconomically backward states of Bihar, Chhattisgarh, Jharkhand, Madhya Pradesh, Orissa, Rajasthan, Uttaranchal and Uttar Pradesh are referred to as the Empowered Action Group (EAG) states (Arokiasamy \& Gautam, 2008).
}

samples from three major regional and culturally distinct scheduled tribes namely, the Bhils, the Meenas and the Saharias of Rajasthan. A structured interview schedule was used as an instrument for data collection, and multi-stage random sampling was employed to draw a sample of 800 ever-married ${ }^{3}$ tribal women of age group 15 to 49 years. ${ }^{4}$ One village and one urban ward from each district were selected as primary sampling unit, and the 50 and 30 samples from each village and urban ward respectively were collected from ten districts. The indicators of women's empowerment considered for this study are women's educational status, employment status, women's participation in household decision-making, media exposure and spousal communication. The 'Children Ever Born' (CEB) ${ }^{5}$ per woman from ever-married tribal women has been considered as the dependent variable. The descriptive analyses have been done to ascertain fertility levels across the independent variables. The linear regression analysis has been applied to examine the causal association between the independent variables and a dependent variable, that is, fertility (CEB).

\section{Results and Discussion}

As stated above, the principal aim of this research is to examine women's empowerment and fertility behaviour amongst the tribals of

\footnotetext{
${ }^{3}$ Ever-married women are those women who have been married at least once in their lives although their current marital status may not be married (United Nations, 2008), retrieved on 10 March from, http://www.un.org/esa/population/publications/WMD2 008/Metadata/EVER_MAR.html.

${ }^{4}$ Women of reproductive age refer to women aged 1549 years which is taken in fertility studies (IIPS, 2014), retrieved on 10 March from, http://rchiips.org/NFHS/NFHS4/manual/NFHS4\%20Interviewer\%20Manual.pdf and http://www.ossyr.org.ar/pdf/bibliografia/2.22.pdf

${ }^{5}$ The number of children ever born (CEB) at various ages of the mother is one measure of a population's fertility. (Haupt et al., 2011), retrieved on 10 March 2018 from, http://www.prb.org/pdf11/prb-population-handbook2011.pdf
} 
Rajasthan. To probe this, the multiple linear regression methods were used. The results from the multiple linear regressions (Table 1) reiterate the relationships between women's empowerment and the size of the family. Women with increasing educational level are likely to have a significantly lower number of children as the standardised beta coefficients for primary education is $(\beta=-0.222, p<0.001)$, secondary and above level stands at $(\beta=-0.336$, $\mathrm{p}<0.001)$. These findings depict the inverse relationships between education and fertility. The analysis, further reveals that women who are engaged in agriculture and casual labour, that is, $(\beta=0.117, p<0.001)$ are likely to have significantly more number of children than their counterparts of unpaid family workers ${ }^{6}$ and family cultivators. However, women who are self-employed, that is, $\left(\beta=-0.027^{\text {ns }}\right)$ and women engaged in government and private jobs are likely to have a lower number of children $(\beta=-0.088, p<0.001)$ than the unpaid family workers and cultivators. This is mainly because the unpaid family workers have decidedly fewer interactions and exposure to social network keeping them unfamiliar to many modern or temporary methods of contraception. While those women working outside home interact with others on reproductive issues and, in this way, perhaps, gains more awareness about the different family planning methods. The results further demonstrate that the exposure to the media also plays a significant determinant of fertility behaviour amongst women. The findings demonstrate that those women who read newspapers $(\beta-0.283, p<0.001)$, listen to the radio $(\beta-0.151, p<0.001)$, watches TV $(\beta-0.154$, $p<0.001)$, and visits the cinema $(\beta-0.125$, $\mathrm{p}<0.001$ ), are more likely to have lower children than their counterparts who do not pursue any of the above.

\footnotetext{
${ }^{6}$ Unpaid family workers are workers within the family whose work is categorised as marginal and is not included in paid income for the family. Unpaid family workers include homemakers, elder caregivers, and children engaged in economic activities but are not remunerated (Daly, 1982).
}

Evidently, women's participation in the household decisions is an essential indicator of women's empowerment, which empowers women to execute their fertility behaviour. The results of the linear regression seemingly demonstrate that those women who participate in household decision-making $(\beta=-$ $0.305, p<0.001$ ) are likely to have lower children than those women who do not. Further, the results of linear regression unravel that those tribal women who had spousal communication on reproductive issues were more likely to have lower fertility $(\beta=-0.097$, $p<0.001)$ than their counterparts who did not have marital communication.

From the above analysis reinforced by field observations, one can deduce that traditional socio-cultural taboos and limited reach to infrastructural facilities have governed mainly the fertility behaviour of the women of Meena, Bhil, and Saharia communities. However, many recent studies have illustrated that the developmental initiatives have made dramatic changes in the fertility behaviour of the tribal women. The findings of this research highlight that the rise in educational status and the changing role of women have led to the significant decline in fertility (Table 2). The findings echo the findings of many previous researches (Koppen, 2006; Melinda et al., 2008; Kravdal, 2001; Dreze and Murthi, 2001; Blake and Delpinal, 1982; Jain, 1981; Caldwell, 1980; Rindfuss et al., 1980; Mahadevan, 1979; Cochrane, 1979; Berelson, 1976; Bogue, 1969; Driver, 1963).

The results bolster the point that education empowers women, which subsequently improves reproductive health and rationalises fertility behaviour. Educated women are far more concerned about the cost of raising children and the difficulties associated with large family sizes. Moreover, educated women have better access to temporary contraceptive methods than their counterparts who have less education (Patidar \& Singh, 2014). In the study area, fertility decreases with increasing education. 
Table 1: Multiple Linear Regression (Unadjusted) Showing the Standardized Beta Coefficients and Confidence Interval (95\%) for Children Ever Born (CEB) by Background Characteristics of Women

\begin{tabular}{|c|c|c|c|c|}
\hline \multirow{2}{*}{$\begin{array}{l}\text { Characteristics } \\
\text { Empowerment }\end{array}$} & \multirow{2}{*}{$\begin{array}{l}\text { Unstandardised } \\
\text { Coefficients }\end{array}$} & \multirow{2}{*}{$\begin{array}{l}\text { Standardised } \\
\text { Coefficients } \\
\text { (Beta) }\end{array}$} & \multirow{2}{*}{$\begin{array}{l}95 \% \\
\text { Interval } \\
\text { Lower }\end{array}$} & Confidence \\
\hline & & & & Upper \\
\hline \multicolumn{5}{|l|}{ Educational Status } \\
\hline No education ${ }^{\circledR}$ & 3.305 & & & \\
\hline Primary education & -1.207 & $-0.222 * *$ & -1.565 & -0.850 \\
\hline Secondary \& above & -1.898 & $-0.336 * *$ & -2.268 & -1.528 \\
\hline \multicolumn{5}{|l|}{ Employment Status } \\
\hline Unpaid family workers ${ }^{\circledR}$ & 2.828 & & & \\
\hline Agricultural and casual labourers & 0.904 & $0.117 * *$ & 0.373 & 1.435 \\
\hline Self-employed & -0.495 & $-0.027^{\text {ns }}$ & -1.777 & 0.788 \\
\hline Govt. and Pvt. Jobs & -0.893 & $-0.088 * *$ & -1.594 & -0.191 \\
\hline \multicolumn{5}{|c|}{ Participation in Household Decision-making } \\
\hline Do not take decision ${ }^{\circledR}$ & 3.274 & & 3.103 & 3.446 \\
\hline Jointly take decision & -0.353 & $-0.063^{\mathrm{ns}}$ & -0.739 & 0.033 \\
\hline Own take decision & -1.337 & $-0.305 * *$ & -1.638 & -1.036 \\
\hline \multicolumn{5}{|l|}{ Media Exposure } \\
\hline \multicolumn{5}{|l|}{ Reading newspapers } \\
\hline Never ${ }^{\circledR}$ & 3.087 & & & \\
\hline Daily or sometimes & -1.546 & $-0.283 * *$ & -1.910 & -1.182 \\
\hline \multicolumn{5}{|l|}{ Listening Radio } \\
\hline Never $^{\circledR}$ & 2.924 & & & \\
\hline Daily or sometimes & -1.272 & $-0.151 * *$ & -1.852 & -0.692 \\
\hline \multicolumn{5}{|l|}{ Watching TV } \\
\hline Never ${ }^{\circledR}$ & 3.117 & & 2.938 & 3.296 \\
\hline Daily or sometimes & -0.613 & $-0.154^{* *}$ & -0.885 & -0.340 \\
\hline \multicolumn{5}{|c|}{ Spousal Communication on Reproductive Issues } \\
\hline No ${ }^{\circledR}$ & 3.272 & & 2.971 & 3.572 \\
\hline Yes & -0.467 & $-0.097 * *$ & -0.805 & -0.129 \\
\hline
\end{tabular}

Fertility among illiterate women is higher (CEB 3.30) than women with primary (CEB 2.10) and secondary \& above educational level (CEB 1.41). There is also evidence to suggest that the employability of women too influences the fertility behaviour. Studies reveal that working women have relatively lower fertility when compared to their non-working counterparts (Weller, 1977; Germain, 1975; Goldstein 1972; Whelpton et al., 1966; Stycos, 1965; Jaffe and Azumi, 1960; Mahmud, 1988, Sivasankaran,
2014). The working women have more autonomy in the decision-making process as well as access to more significant opportunities to interact with others on several reproductive and family issues. The tribal women who are engaged in agriculture and casual paid labourers have higher fertility (CEB 3.73) than the unpaid family workers (CEB 2.83), selfemployed (CEB 2.33), and government and private services (CEB 1.94). 
Table 2: Children Ever Born (CEB) per Woman by Characteristics of Women's Empowerment

\section{Characteristics of Women's Empowerment}

Educational Status

\begin{tabular}{lll}
\hline No education & 3.30 & 564 \\
\hline Primary education & 2.10 & 123 \\
\hline Secondary and above & 1.41 & 113 \\
\hline Employment Status & & 704 \\
\hline Unpaid family workers & 2.83 & 56 \\
\hline Agriculture and casual labourers & 3.73 & 9 \\
\hline Self-employed & 2.33 & 31 \\
\hline Govt. and Pvt. Services & 1.94 & \\
\hline Participation in Household Decision-making & & 463 \\
\hline Don't take own decision & 3.27 & 114 \\
\hline Take joint decision & 2.92 & 223 \\
\hline Take own decision & 1.94 & \\
\hline
\end{tabular}

Media Exposure

Reading newspapers

\begin{tabular}{lll}
\hline Never & 3.09 & 678 \\
\hline Daily or Sometimes & 1.54 & 122 \\
\hline Listening Radio & & \\
\hline Never & 2.92 & 754 \\
\hline Daily or Sometimes & 1.65 & 46 \\
\hline Watching TV & 3.12 & 453 \\
\hline Never & 2.50 & 347 \\
\hline Daily or Sometimes & & 162 \\
\hline Spousal Communication on Reproductive Issues & 3.27 & 608
\end{tabular}

Source: Based on Personal Field Survey, 2011

As explained above, the unpaid family workers are those women who are homemakers or work in their agricultural fields as cultivators. Women who work as labourers receive low wages and therefore, they need more people to earn for the family. While women who are self-employed and are in services receive regular and satisfactory salaries, it is reckoned that they do not, need larger family size and give preference to small families. However, further research is required to prove this rationale.

Many previous studies have reported that women's household decision making have been negatively associated with the desire to have children (Steele et al., 1998; Woldemicael, 2009). Women's own and joint household decision-making produce differential reproductive outcomes (DeRose and Ezeh, 2010). The results from linear regression validate these studies. Thus, this study unfolds that the tribal women of Meena, Bhil and Saharia communities who take household decisions for their own have relatively lower fertility rates (CEB 1.94) when compared to those women who do not participate in household decision making (CEB 3.27) and also to those women who take decisions jointly with other family members (CEB 2.94).

Further, as demonstrated above, the media exposure through television, radio, and newspapers plays a crucial role to promote many health issues, including small family size, family planning methods, immunisation and a number of other public health services. Many studies have revealed that the media exposure
Children Ever Born (CEB) per Woman

Number 
has a significant impact on the fertility behaviour of women too (Stuart, 2010, Rabbi, 2012, Williams \& Singh, 1976). This research seemingly showed that women who read newspapers either daily or occasionally have relatively lower fertility (CEB 1.54) than their counterparts (CEB 3.09) who do not read newspapers. Similarly, women listening to the radio also have more moderate fertility (CEB 1.65) than those who fail to listen to the same (CEB 2.92). Television has become an essential medium in disseminating various awareness programmes about health and family welfare issues (Basten, 2010). This research highlights that women watching television have lower fertility (CEB 2.50) than those who never watch television (CEB 3.12). As stated above, the spousal communications on reproductive issues too influence the reproductive desires of the couple (Kumar et al., 2016). It is thought that fertility decision is a combined decision of couples, but in reality and as demonstrated in this research, such decisions are taken either by the husbands or by the elders in the family. The reproductive behaviour of men and women may differ considerably, and the communication between them makes relatively a more rational fertility decision. This finding reinforces previous research (Oyediran et al., 2006). The women who communicate with their spouses on reproductive issues such as desired family size, sex of children, birth interval, contraceptive methods and natal care have significantly lower fertility (CEB 2.80) than those who do not have any communication with their husbands (CEB 3.27).

\section{Conclusion}

The aim of the present research was to examine women's empowerment and the reproductive behaviour amongst the women of three tribal communities of Rajasthan-the Meenas, Bhils and the Saharias. Evidently, India has experienced rapid fertility decline with its rapid socio-economic transformation. The constant efforts of the Central government and the respective state governments in this connection have played significant roles. Women's empowerment has been an important factor in fertility outcomes. The findings show that power within and power to are crucial to the tribal women's empowerment and their fertility behaviour. The results demonstrate that education, employability, household decision-making, media exposure, and spousal communication are found to be significant indicators of fertility behaviour amongst the women of the Meenas, Bhils and Saharias. From the analysis, one can presume that Rowland's $(1995 ; 1997)$ power within and power to (Bhattacharyya, 2009; Bhattacharyya, 2016; Bhattacharyya and Vauquline 2013) are the keys mediating the fertility behaviour amongst the women of these three communities. It can be argued that the results of this research empirically confirm the findings of previous studies (Koppen, 2006; Melinda et al., 2008; Kravdal, 2001; Dreze and Murthi, 2001; Blake and Delpinal, 1982; Jain, 1981; Caldwell, 1980; Rindfuss et al., 1980; Mahadevan, 1979; Cochrane, 1979; Berelson, 1976; Bogue 1969; Driver, 1963).

From the research findings, it is urged for an urgent need for the development of an effective strategy to strengthen the infrastructure, so that the tribal women of the marginal and isolated areas may get access to it. Women need to be empowered by creating a safe space for them, supporting their mobility and independence in and out of the homes, promoting saving among them, generating skills through training, boosting their decisionmaking skills, improving their reproductive health and providing better education to them. The 'Right of Children to Free and Compulsory Education' (Right to Education Act, 2009) of the Government of India (GOI, 2010) is crucial in this regard. Yet, the substantial shares of the people from the ST communities do not access to education or have been dropping out due to poverty and geographical constraints. The media should promote women's awareness toward family issues more intensively so that women may take fertility decision on their own. The study may have some policy implications for future studies pertaining to fertility and for the policy makers who aim to regulate fertility. 


\section{References}

Arokiasamy, P. \& Gautam, A. (2008). Neonatal mortality in the empowered action group states of India: trends and determinants. Journal of Biosocial Science, 40(2):183-201.

Berelson, B. (1976). Social Science research on population: A Review. Population and Development Review, 2 (2), 219-266.

Basten, S. (2010). Television and fertility. Finnish Yearbook of Population Research, 55, 67-82.

Bhardwaj, S. \& Tungdim, M. G. (2010). Reproductive health profile of the Scheduled Caste and Scheduled Tribe women of Rajasthan, India. The Open Anthropology Journal, 3, 181-187.

Bhattacharyya, R. (2009). Examining the changing status and role of middle class Assamese women: lessons from the lives of university students. PhD Thesis, University of Newcastle, United Kingdom. Retrieved on 28 February 2018 from, https://theses.ncl.ac.uk/dspace/handle/10443/ 303

Bhattacharyya, R. (2013). Are we empowered? Stories of young Indian working women, Saarbrücken, Germany: Lap Lambert Academic Publishing, (ISBN: 978-3-659-20580-4)

Bhattacharyya, M. (2016). Drawing a linkwomen's empowerment and Mahatma Gandhi National Rural Employment Guarantee Act: A study conducted in the Goalpara District, Assam, Space and Culture, India, 3(3), 21-27, doi:10.20896/saci.v3i3.180

Bhattacharyya, R. \& Vauquline, P. (2013). A mirage or a rural life line? Analysing the impact of Mahatma Gandhi Rural Employment Guarantee Act on women beneficiaries of Assam. Space and Culture, India, 1(1), 83-101. doi:10.20896/saci.v1i1.10

Blake, J. \& Delpinal, J. (1982).Educational attainment and reproduction preferences: Theory and Evidence. In C. John \& R. Mackensen, (eds) Determinants of fertility trends: Theories Re-Examined, Liege:
International Union for the Scientific Study of Population, (IUSSP).

Bogue, D. J. (1969). Principles of demography. New York: John Wiley and Sons.

Caldwell, J. C. (1980). Education as a factor in mortality decline: An examination of Nigerian data. Population Studies, 33(3): 395-413.

Census of India (2011). Primary census abstract. Office of the Registrar General \& Census Commissioner, India, Ministry of Home Affairs, Government of India

Cochrane, S. H. (1979). Fertility and education: what do we really know?. World Bank staff Occasional Papers; No. OCP 26. Baltimore, MD: The Johns Hopkins University Press.

Daly, P. A. (1982). Unpaid family workers: longterm decline continues. Monthly Labor Review.105 (10), 3-5. Retrieved on 11 January 2018 from, https://stats.bls.gov/opub/mlr/1982/10/art1ful I.pdf

DeRose, L. F. \& Ezeh, A. C. (2010).Decision making patterns and contraceptive use: Evidence from Uganda. Population Research and Policy Review,29(3), 423-439. Retrieved on 08 February 2018 from, http://paa2007.princeton.edu/papers/70594

Dreze, J. \& Murthi, M. (2001).Fertility, education and development. Population and Development Review, 27(1), 33-63.

Driver, D. (1963).Differential fertility in Central Edwin. India, Princeton: Princeton University Press.

Germain, A. (1975). Status and role of women as factors in fertility behaviour: A policy analysis, Studies in Family Planning, 6(7), 192-200.

GOI, (2010). The right of children to free and compulsory education (RTE) act, 2009.Ministry of Law and Justice, Government of India.

Goldstein, S. (1972). The Influence of labour force and education in Thailand, Population Studies, 26(3), 419-436.

Gupta, M. D. (1996). Life course perspectives on women's autonomy and health outcomes. 
Health Transition Review, Supplement 6, 213231.

Haupt A., Kane, T. T., Haub, C. \& Population Reference Bureau (2011). The Population Reference Bureau's population handbook. Washington, D.C: Population Reference. Retrieved on 11 March from, http://www.prb.org/pdf11/prb-populationhandbook-2011.pdf

International Institute for Population Sciences \& ICF (2017). National Family Health Survey

(NFHS-4), 2015-16: India, Mumbai, IIPS.

International Institute for Population Sciences (2014). National Family Health Survey 2015-16 (NFHS-4) Interviewer's Manual. Mumbai, IIPS. Retrieved on 11 March from, http://Rchiips.Org/Nfhs/Nfhs4/Manual/Nfhs4\%20interviewer\%20manual.Pdf

Jacobson, J. (1992). Gender bias: Roadblock to sustainable development. Worldwatch Paper, no. 110. Washington, Worldwatch Institute.

Jaffe, A. J. \& Azumi, K. (1960). The birth rates and cottage industries in under developed countries. Economic Development and Cultural Change, 9 (1), 52-63.

Jain, A. K. (1981).The effect of female education on fertility: A simple explanation. Demography, 18(4), 577-595.

Jejeebhoy, S. J. (1995). Women's education, autonomy, and reproductive behaviour: Experience from developing countries. Oxford: Clarendon Press.

Kabeer, N. (1999). Resources, agency, achievements: Reflections on the measurement of women's empowerment. Development and Change, 30, 435-464.

Kabeer, N. (2005). Gender equality and women's empowerment: A critical analysis of the third millennium development goal. Gender \& Development, 13(1), 13-24.

Koppen, K. (2006). Second births in Western Germany and France. Demographic Research, 14(14), 295-330. Retrieved 30 December from, https://www.demographicresearch.org/volumes/vol14/14/14-14.pdf.
Kravdal, O. (2001). The high fertility of college educated women in Norway: An artifact of the separate modelling of each parity transition. Demographic Research, 5(6), 187-216.

Retrieved on 30 November from, https://www.demographicresearch.org/volumes/vol5/6/5-6.pdf.

Kumar D., Kalia, M., Goel, N. K. \& Sharma, M. K. (2016).Differentials of spousal communications and reproductive desires of couples in urban slums of Chandigarh, India.International Journal of Community Medicine and Public Health, 3(9), 2637-2644. Retrieved on 28 January from, http://dx.doi.org/10.18203/23946040.ijcmph20163088.

Mahadevan, K. (1979). Sociology of fertility: Determinants of fertility differentials in South India. New Delhi: Sterling Publishers, Pvt. Ltd.

Mahmud, S. (1988). Exploring the relationship between women's work and fertility: the Bangladesh context. Bangladesh Development Study, 16(4), 99-113.

Majumdar, D. N. (1947). The matrix of Indian Culture. Lucknow: The Universal Publications Ltd.

Melinda, M., Mencarini, L., Tanturri, M. L. \& Begall, K. (2008). Gender equity and fertility intentions in Italy and the Netherlands. Demographic Research, 18(1), 1-26. Retrieved on 20 January 2018 from, https://www.demographicresearch.org/volumes/vol18/1/18-1.pdf.

Nag, M. (1973). Tribal-non-tribal fertility differentials in India. Demography India, 2(1), 104-120.

Nagda, B. L. (2003). Ethno-demographic determinants of high fertility among Tribes. Anthropologist, 5(3), 185-188.

Nanda, S. (2005). Demography and ethnography of fertility behaviour: A study of non-industrial population in India. Journal of Human Ecology, 18(4), 301-308.

Oyediran, Kola \& Abenihe-Isiugo, U.C. \& Akinrinola, B. (2006). Correlates of spousal communication on fertility and family planning 
among the Yoruba of Nigeria. Journal of Comparative Family Studies. 37(3), 441-460.

Patidar, H. \& Singh, M. B. (2014). Knowledge and use of contraceptive methods among tribal women: Evidence from South-East Rajasthan, India.International Journal of Current Research, 6(8), 7927-7934.

Patidar, H. (2015). Pregnancy outcomes among adolescent tribal women: Insights from SouthEast Rajasthan, India. Epidemiology, Biostatistics and Public Health,12(2), 1-9.

Phan, L. D. (2016). Women's empowerment and fertility preferences in South East Asia. A thesis submitted in fulfilment of the requirements for the Degree of Doctor of Philosophy. The University of Sydney, Sydney, Australia.

Rabbi, A. M. F. (2012).Mass media exposure and its impact on fertility: Current scenario of Bangladesh. Journal of Scientific Research, 4(2), 383-395.

Rindfuss, R. R., Bumpass, L., St. John, C. (1980). Education and fertility: implications for the roles women occupy. American Sociological Review, 45 (1), 431-447.

Rindfuss, R. R. \& Brewster K. L., (1996). Childrearing and fertility. Population and Development Review, 22 (Supplement), 258289.

Roth, E. A., Ray, A. K. \& Mohanthy, B. (1983). The Delineation of fertility strategies in a tribal population of India: The Koyas of Koraput district, Orissa. Journal of Anthropological Research, 39 (3), 65-76. Retrieved 30 November 2017 from, http://www.journals.uchicago.edu/doi/abs/10. 1086/jar.39.3.3629671.

Rowlands, J. (1995). Empowerment examined, Development in Practice, 5(2), $101-107$

Rowlands, J. (1997). Questioning empowerment: Working with women in Honduras. London, Oxfam.

Singh M. B. \& Patidar H. (2012). Socio-economic and demographic correlates of fertility: Evidence from tribals of South-East Rajasthan.
National Geographical Journal of India, 58 (2), 1-12.

Sivasankaran, A. (2014). Work and women's marriage, fertility and empowerment: Evidence from textile mill employment in India, Job market paper. Retrieved 20 January 2017 from, https://scholar.harvard.edu/files/asivasankaran /files/jobmarketpaper_anithasivasankaran.pdf.

Steele, F., Aminand, S. \& Naved, R. T. (1998). The impact of an integrated micro-credit program on women's empowerment and fertility behavior in rural Bangladesh. Policy Research Division Working Paper no 115, Washington, DC: The World Bank.

Stuart, B. (2010). Television and fertility. Finnish Yearbook of Population Research, 65, 67-82.

Stycos, J. M. (1965). Female employment and fertility in Lima, Peru. Milkbank Memorial Fund Quarterly, 43(1), 42-54.

United Nations (2014). The world survey on the role of women in development 2014: Gender equality and sustainable development. New York: United Nations.

United Nations (2015). Sustainable development goals. United Nations. New York. Retrieved 10 December from, http://www.un.org/sustainabledevelopment/s ustainable-development-goals/.

United Nations, (1961). Mysore population study, Department of Economic and Social Affairs, Population Studies, no. 34.

United Nations, (1996). Report of the fourth World Conference on women, 4-15 September 1995, New York: United Nations.

United Nations Population Information Network (1995). Guidelines on women's empowerment. New York.

United Nations, Department of Economic and Social Affairs, Population Division (2009). World Marriage Data 2008 (POP/DB/Marr/ Rev2008).

United Nations (2015). World fertility patterns 2015. Population Division, Department of Economic and Social Affairs, United Nations. 
Verma, K. K. (1977). Culture, ecology and population: An anthropo-demographic study. New Delhi: National Publishing House.

Weller, R. H. (1977). Demographic correlates of women's participation in economic activities. In Proceedings of the International Population Conference, 1977 held in Mexico, IUSSP.

Whelpton, P. K., Campbell, A. A., Patterson, J. E. (1966). Fertility and family planning in the United State. New Jersey: Princeton University Press.
Williams, J. S. \& Singh, B. K. (1976).The impact of mass media on fertility rates: An exploration. Journal of Applied Communication Research, 4(1), 19-24. Published online on 21 May 2009. http://dx.doi.org/10.1080/0090988760936022 2.

Woldemicael, G. (2009). Women's autonomy and reproductive preferences in Eritrea. Journal of Biosocial Science, 41(2), 161-181. 